\section{Linking leptin to serotonin}

\section{By Tim Fulmer, Senior Writer}

Columbia University researchers and colleagues have shown for the first time how leptin exerts its effects on appetite and bone mass. ${ }^{1}$ The missing link is serotonin receptors in the hypothalamus $-5-\mathrm{HT}_{1 \mathrm{~A}}$ for appetite and $5-\mathrm{HT}_{2 \mathrm{C}}$ for bone mass.

The team has plans to antagonize the former receptor subtype to treat obesity. But the new model of leptin signaling appears to contradict clinical results from Arena Pharmaceuticals Inc.'s lorcaserin, a selective $5-\mathrm{HT}_{2 \mathrm{C}}$ agonist that significantly reduced body weight of participants in Phase III obesity trials.

Leptin is secreted by peripheral adipose tissue, and the hormone is thought to bind its receptor on neurons in the hypothalamus to regulate appetite. However, deletion of the leptin receptor on hypothalamic neurons has a very mild effect on weight gain, ${ }^{2}$ suggesting that leptin regulates food intake and energy metabolism via neurons outside the hypothalamus.

The Columbia researchers previously showed an additional role for leptin: indirect regulation of bone metabolism via neuronal pathways in the CNS rather than direct interaction with bone. ${ }^{3,4}$

Taking those two sets of findings together, the group hypothesized that

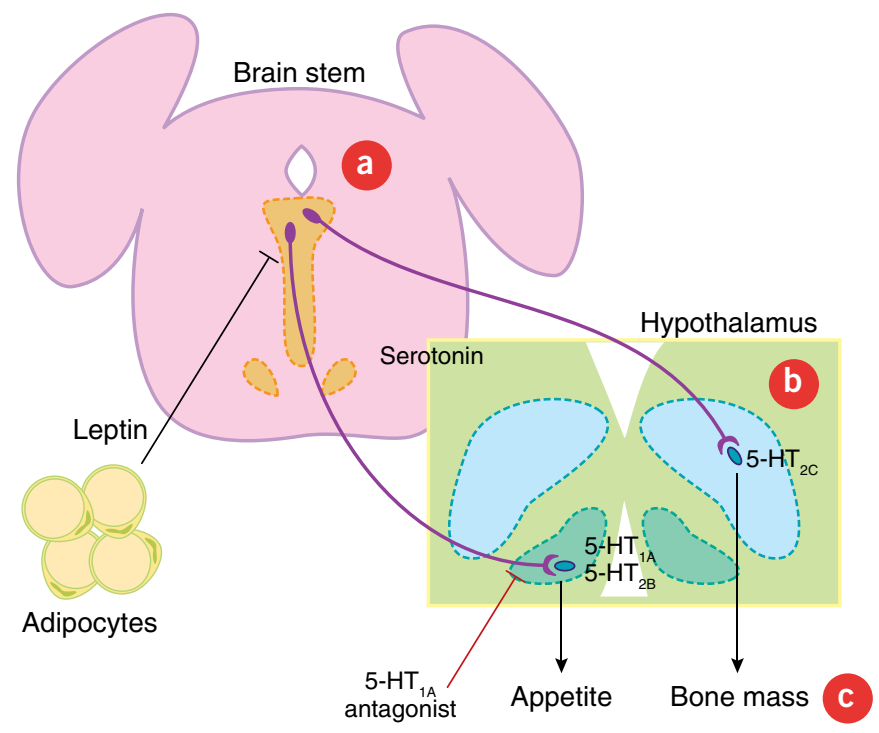

Figure 1. The leptin-serotonin axis of obesity. leptin initially binds its receptor on neurons outside the hypothalamus and triggers the release of an intermediary neurotransmitter that binds hypothalamic neurons to modulate appetite and bone mass.

The latest findings, published in Cell, are based on data from serotonin knockout mice and support the hypothesis. Thus, targeting serotonin receptors on hypothalamic neurons apparently could offer a way to modulate appetite and food intake independent of circulating leptin levels. This is important because chronic obesity is often associated with leptin resistance that makes administration of leptin itself problematic.

According to the mechanism proposed in the paper (see Figure 1, “The leptin-serotonin axis of obesity"), leptin secreted by peripheral adipocytes binds its receptor on serotonin-producing neurons in the brain stem (see Figure 1[a]), which blocks firing of those neurons and decreases the activity of neurons in the hypothalamus (see Figure $\mathbf{1}[\mathbf{b}]$ ). Attenuated signaling in hypothalamic neurons then triggers two types of alterations in the periphery: decreases in both appetite and accrual of bone mass (see Figure 1 $[\mathbf{c}]$ ).

The alterations in appetite and bone mass are mediated by two different subtypes of serotonin receptor in the hypothalamus. The serotonin $5-\mathrm{HT}_{1 \mathrm{~A}}$ and $5-\mathrm{HT}_{1 \mathrm{~B}}$ receptors mediate appetite, whereas the serotonin $5-\mathrm{HT}_{2 \mathrm{C}}$ mediates accrual of bone mass.

The researchers now want to take advantage of those different subtypes to design an obesity therapy that selectively decreases appetite without negatively affecting bone mass.

"One of our key next steps is to design and test compounds that selectively inhibit the serotonin $5-\mathrm{HT}_{1 \mathrm{~A}}$ receptor on hypothalamic neurons and thus blunt appetite without also blocking the serotonin $5-\mathrm{HT}_{2 \mathrm{C}}$ receptor and triggering unwanted loss of bone mass," said Gerard Karsenty, corresponding author on the paper and professor of genetics and development at the Columbia University Medical Center.

Karsenty added that leptin therapy should be avoided in this context "because it is predicted to trigger bone loss in addition to appetite suppression and could put obesity patients at risk of bone disorders like osteoporosis."

The model isn't airtight. Indeed, the work published in Cell would predict that agonizing the serotonin $5-\mathrm{HT}_{2 \mathrm{C}}$ receptor would enhance accrual of bone mass.

In the clinical setting, however, rather than accrual of bone mass, agonizing 5- $\mathrm{HT}_{2 \mathrm{C}}$ has led to weight loss. Last week, Arena announced that its lorcaserin $5-\mathrm{HT}_{2 \mathrm{C}}$ agonist induced a $5 \%$ loss of body weight compared with placebo in the Phase III BLOSSOM (Behavioral Modification and Lorcaserin Second Study for Obesity Management) trial. The results were statistically significant.

Karsenty acknowledged that the model does not predict that a $5-\mathrm{HT}_{2 \mathrm{C}}$ agonist such as lorcaserin would induce weight loss.

Two possible explanations come to mind: that mouse and human brains are wired differently or that lorcaserin works via a different mechanism than postulated. However, both Karsenty and Arena declined to comment on the discrepancy.

The findings in Cell are patented and available for licensing from the Columbia University technology transfer office, Karsenty told SciBX. 


\section{TARGETS \& MECHANISMS}

Fulmer, T. SciBX 2(37); doi:10.1038/scibx.2009.1396

Published online Sept. 24, 2009

\section{REFERENCES}

1. Yadav, V. et al. Cell; published online Sept. 4, 2009; doi:10.1016/j.cell.2009.06.051

Contact: Gerard Karsenty, Columbia University, New York, N.Y. e-mail: gk2172@columbia.edu
2. Balthasar, N. et al. Neuron 42, 983-991 (2004)

3. Elefteriou, F. et al. Nature 434, 514-520 (2005)

4. Shi, Y. et al. Proc. Natl. Acad. Sci. USA 105, 20529-20533 (2008)

COMPANIES AND INSTITUTIONS MENTIONED

Arena Pharmaceuticals Inc. (NASDAQ:ARNA), San Diego, Calif. Columbia University, New York, N.Y. 